\title{
CONSEQUENCES OF CRIMINAL OFFENSES: IMPACT ON THE ECONOMIC SECURITY OF COUNTRIES AND OPENING IN THE GLOBALIZATION CONDITIONS
}

\author{
Bogdan Schur ${ }^{1}$, Rostyslav Lemekha ${ }^{2}$
}

\begin{abstract}
In the context of globalization, the development of foreign trade, the simplification of customs formalities, the strengthening of economic relations with the EU and other countries of the world are priorities of the foreign economic policy of most countries of the world. At the same time, the priority is to ensure national security, in particular, such components as economic, including customs, environmental security, protection of interests of public and private persons, domestic producers, compliance with the requirements of international pacts, other instruments ratified by a particular state. In this regard, particular attention is given today to the problems of international trade liberalization through customs policy instruments, in accordance with the International Convention (Kyoto Convention) on the simplification and harmonization of customs procedures dated 18 May 1973, the provisions of which concern cooperation with authorities, customs services, including those in the field of counteraction to customs offenses, which include any violation of customs legislation (Kyoto Convention, 1973). The key to the development of states' social security is the stability of receiving revenues to the budgets of all levels, which are paid by taxpayers in accordance with certain regulations on the basis of voluntariness. Despite the recognition of the urgent task of establishing close interaction and activation of common efforts to counter violations in this area, it is quite difficult to harmonize the provisions of current legal acts in the EU countries regarding the definition of such concepts as "smuggling", "counterfeit", etc. as a variety of offenses in the customs field, establishing the consequences and the main measures of responsibility for their commission. According to a study by Frontier Economics, each year, the counterfeit costs the G20 countries 2.5 million jobs and about $\$ 120$ billion in lost taxes and increased costs of crime, the cost of treatment and death costs resulting from the use of dangerous counterfeit goods (Iliupolu, 2017). The urgency of detecting offenses in the customs field, the use of the most effective tools aimed at preventing their spread, stopping and preventing negative consequences can hardly be denied. At the same time, the quality of such instruments is characterized, on the one hand, by the indicators of securing the expected budgetary revenues, which will allow the implementation of the approved Government programs for social protection of the population, on the otherthe maximum focus on maintaining positive gains in forming a favorable business climate, the possibility of continuation by them, activities in the field of economics in the regulatory field. This research is aimed at solving this problem. Methodology. The achievement of the purpose of this publication is based on the cognitive potential of a number of philosophical, general scientific and special methods. The main method of research, given the desire to determine the directions of development of national scientific opinion on the subject of the publication, was the dialectical methods of analysis and synthesis, the comparativelegal method allowed to identify promising measures to counteract these offenses, taking into account the experience of highly developed EU countries. Methods of grammatical consideration and interpretation of legal norms contributed to the identification of gaps and other shortcomings of the legislation governing the grounds and the procedure for bringing to justice the perpetrators of them, to develop proposals for its improvement. Practical implications. Experience of formation and development of quality assurance of legal institutions defining the principles of activity of subjects of the national security system is connected with the clarity of determining the consequences of offenses including, in the customs sphere, activation of
\end{abstract}

\footnotetext{
Corresponding author:

${ }^{1}$ Lviv University of Trade and Economics, Ukraine.

E-mail: bogdanshchur1965@ukr.net

${ }^{2}$ Danylo Halytsky Lviv National Medical University Ukraine.

E-mail: roslemekha@gmail.com
} 
Vol. 5, No. 5, 2019

Baltic Journal of Economic Studies

means of their neutralization with the use of justifiable coercion, to the extent corresponding to public the dangers and consequences of such an offense.

Key words: customs offenses, administration of customs payments, efficiency of customs clearance procedures, counteracting smuggling, stopping the spread of counterfeits, administrative liability, criminal responsibility for the right of violation in the customs sphere.

JEL Classification: O34, K11, K14, K23

\section{Introduction}

Due to the lack of functional capacity of the state institutions, which are designed to counteract the spread of offenses, the public distrust of the controlling bodies, the legal nihilism of a large part of the population, not only in Ukraine but also in many EU countries, the volume of violations of customs rules are increasing. The most dangerous of them are those defined by international instruments, such as smuggling. The subject of this crime is defined in each national code depending on the actuality of legal protection of certain interests, goods, etc. In particular, in Ukraine the criminalized trafficking subjects include: cultural values, poisonous substances, explosives and radioactive substances, weapons or ammunition (except for smooth-bore hunting weapons or ammunition to it), parts and firearms on various weapons, as well as special technical and means and secret information (according to the Criminal Code of Ukraine (Article 201 of the Criminal Code of Ukraine)), timber of valuable and rare trees, untreated timber, banned for export outside the customs territory of Ukraine (Article 201-1 of the Criminal Code of Ukraine)) ; narcotic drugs, psychotropic substances, their analogs or precursors or counterfeit drugs (Article 301 of the Criminal Code of Ukraine) (the Criminal Code of Ukraine, 2001).

In addition, these violations, which are criminally punishable under the criminal law of many countries, imperfect legal regulation, which is subject to systematic and not always systematic interference, does not create an obstacle for the actions for which the responsibility is provided by administrative and legal norms. In addition, a significant percentage of abuse of privileges when importing goods in post items for resale, with the aim of avoiding payment of duties, which becomes a catalyst for increasing the shadow economy in the country.

Increasing risks and threats of destabilization of the economic security of the state, causes aggravation of the socio-economic situation in society, deterioration of the quality of life of the population and the emergence of unhealthy competition in the market (Tylchyk, Tylchyk, 2018). Increasing the impact of destabilizing tendencies on ensuring the economic security of the state requires the development of priority directions for its strengthening.

\section{Determination of the consequences caused by offenses in the customs sphere}

Given the different types of offenses, their consequences are related to the harm of the following two main groups. Firstly, the economic and social ones (as a result of the entry into the market of counterfeit and pirated products, the state loses its monopoly on the export/import of certain groups of goods, especially those which are excluded from the general list of turnover and national producers suffer significant losses due to loss of demand for domestic products; shortfall in full budget revenues; encourages the spread of unfair competition).

Secondly, security: things, substances that pose a danger to society, life, human health, ecology, violations of human rights of individuals, in particular in the case of smuggling of cultural values, etc., get into uncontrolled circulation. The cross-border e-commerce market is projected to grow to $\$ 1$ trillion in 2020 and about 1 billion people worldwide will make crossborder online purchases of goods. By 2022, crossborder B2C e-commerce will account for one-fifth of total online retail sales. Cross-border e-commerce is projected to deliver one-fifth of total online retail sales by 2022 (National Small and Medium Business Platform, 2019).

Thirdly, institutional: since the intensification of the growth of smuggling and counterfeit products with the state resources invariable for their control and administration requires optimization, given the limited human resources of the customs authorities.

The question of the effectiveness of combating irregularities in the customs sector and supporting public administration structures to reduce the incidence of such violations is the focus of research by such organizations and institutions, in particular:

- by international organizations: within the OECD Task Force on Countering Illicit Trade - Illicit Trade: Converging Criminal Networks (April 2016); Trade in Counterfeit and Pirated Goods: Mapping the Economic Impact (April 2016); Governance Frameworks to Counter Illicit Trade (March 2018) and World Customs Organization - WCO Study Report on Cross-Border E-Commerce (March 2017); Communication from the International Customs Community on Cross-Border E-Commerce (December 2017);

- EU institutions (European Commission, European Anti-Fraud Office or OLAF, EU Intellectual Property 
Office or EUIPO) - Digital Traceability in the fight against Illicit Trade: Improving rules and practices (November 2017); Enforcers and brand owners' empowerment in the fight against counterfeiting (October 2017); Synthesis Report on IPR Infringement (June 2018);

- the public sector (Coalition Against Illicit Trade or CAIT, Institute for Economic Research and Policy Consulting) - Implementing digital solutions to address the issue of cross border illicit trade (November 2017); Mailing and Importing: Realities in Ukraine and International Practice (October 2017). In 2018, the OECD issued the Framework Standards for Combating Illicit Trade (Cherkashin, 2019).

\section{Characteristics of legal support for the development of institutions of legal responsibility for offenses in the customs sphere}

The problem of the consequences of offenses, especially criminal offenses, is fundamental. Discussions on the formation of approaches on the correlation of consequences and liability in the form of specific types of penalties (for crimes these are the types of punishments) are renewed both during fundamental changes of national legislation and during the introduction of responsibility for certain offenses. In particular, in Ukraine as in other post-Soviet countries, the outlined issue was of paramount importance when drafting the Codes of Independent States. At the same time proclaimed a radical change in the vector of this ratio, in order to approve the declared intentions of forming a human-centered state, with equal opportunities for each person, on the basis of equality before the law.

The recognition of the need for a radical change in the approaches to the concept and content of offenses, their consequences, and punishments, the application of other penalties were reflected in the adopted national criminal codes, adopted in Ukraine in 2001. Compared to other countries, it was rather late, which makes it possible to conclude that the national legislator is prudent and modest about the process and expects high efficiency of novelties, practical acceptance, and recognition by society. Also, it is logical to expect the harmonization of the provisions of the said code with other laws that determine the grounds and procedure for bringing to justice. At the same time, theorists and practitioners have noted both the numerous gaps in the penal code and the lack of resolution of key problems. In particular, the consequences of such a situation were systematic laws amending the new code, which only came into force. Finally, today the issue of rethinking the doctrine of the offenses and the consequences that they have caused has become relevant again. The Law of Ukraine "On Criminal Offenses" was adopted and the updated Criminal Code is being prepared. In addition, the Code of Administrative Offenses remains in force, taking into account the provisions of which most of the provisions of the Customs Code of Ukraine are formulated. Therefore, the problems of improving the system of general and special parts of the Criminal Code, the classification of crimes, in particular on the basis of the severity of the consequences caused, need to be addressed. In the current legislation, it is quite arbitrary and in the absence of unification of indicators characterizing socially dangerous consequences and objects of offenses.

Scientists note the lack of a systematic approach not only in regulatory acts but also among theoretical studies. Noting that quite often, by characterizing one or more offenses and offering completely different amounts of damage, individual researchers do not focus on elaborating common approaches to determining the socially dangerous consequences of offenses. The optimization of the relevant parameters must be unified and of a complex nature.

Authors of the Doctrine of Criminal Law of Ukraine assessing the situation of developing sound value criteria of crime in the sphere of economic activity (respectively tax and customs spheres) emphasize the fact that without conducting thorough criminological and empirical studies it is unlikely to be possible to overcome the risk of quantifiability, as a consequence, failure to comply with the most relevant requirement in the above mentioned areas - the social conditionality of the criminal law Well (Criminal legal science in Ukraine: state, problems and Development, 2013).

Critical reflection on draft normative acts intended to determine the grounds and procedure for bringing persons to legal liability must be combined with the preparation of recommendations on the delimitation of crime, criminal offenses, administrative offenses and so-called "financial offenses". At the same time, it is important to determine the social guidelines, consequences and significance of such proposals by domestic scientists as restoration of criminal responsibility for what they consider to be unreasonably decriminalized acts (evasion of foreign exchange earnings, fictitious business, commodity smuggling, insolvency violations) (Criminal Law in Ukraine: State, Problems and Ways of Development, 2013).

\section{Conclusions}

Considering the need to ensure the harmonization of the criminal legislation of Ukraine and other European countries, it is worth paying attention to the restrictions on borrowing dualism, when criminal law is contained not only in the Criminal Code but also in other laws, even by-laws. On the other hand, the introduction in the legal acts of an approach recognized in most European Union countries regarding the administrative liability of legal entities due to the existence of the concept of 
"objective guilt", according to which the intent and negligence of the offender should not be established, and it is sufficient to state the fact violation of the law by a legal person, the presence of guilt in such case is presumed. In addition to the fine, the legislation of most European countries, in particular, the Code of Administrative Offenses of the Republic of Lithuania provides for the deprivation of the right to engage in entrepreneurial activities, to receive financial assistance from the state, and to confiscate property used to commit an offense (Spivak, 2019).

The major consequences of tax and customs offenses are that the state, and not its controlling bodies, lose control over the production and circulation of goods due to the use of various schemes to reduce the tax burden.

\section{References:}

Iliupolu, A. (2017). Proekt TWINNING provodyt navchannya spivrobitnykiv mytnykh orhaniv [The TWINNIHG project provides training for customs officers]. The official site of the State Service of Intellectual Property of Ukraine. Retrieved from: http://sips.gov.ua/ (accessed 20 November 2019). (in Ukrainian)

Kryminal'nyj kodeks Ukrainy (2001). [The Criminal Code of Ukraine]. Supreme Council of Ukraine. № 25-26, 13.1. (in Ukrainian)

Pashko, P., Tylchyk, O., \& Kotukha, O. (2018). Ontology of scientific cognition of shadow economy and economic shading. Baltic Journal of Economic Studies vol. 4, no. 2, pp. 151-158. doi: 10.30525/2256-0742/2018-4-2-151-158

Tylchyk, O., Pluhatar, T., \& Kotukha, O. (2018). Determinants of shadowing the economy: the genesis of economic and legal doctrines. Baltic Journal of Economic Studies, vol. 4, no. 3, pp. 302-308. doi: 10.30525/2256-0742/20184-3-302-308

Tylchyk, O., Dragan, O., \& Nazymko, O. (2018). Establishing the ratio of counteraction concepts to the legalization (laundering) of illegally-earned income and counteraction to the shadow economy: the importance of determining performance indicators of European integration processes. Baltic Journal of Economic Studies, vol. 4, no. 4, pp. 341-346. doi: 10.30525/2256-0742/2018-4-4-341-345

Tylchyk, O. Riabchenko, Y., \& Popivnik, O. (2018). Management (administrative) activity of controlling authorities in the taxation area: essence and types. Baltic Journal of Economic Studies, vol. 4, no. 5, pp. 343-351. doi: 10.30525/2256-0742/2018-4-5-343-351

Tylchyk, V., Bielai, S., \& Morozov, I. (2018). The innovative approach to crisis situations monitoring of social and economic origin that endanger the security of Ukraine. Baltic Journal of Economic Studies, vol. 4, no. 3, pp. 15-21. doi: 10.30525/2256-0742/2018-4-3-15-21

Tylchyk, V., Jankovska, L., \& Khromyshin, I. (2018). National economic security: an economic and legal framework for ensuring the conditions of European integration. Baltic Journal of Economic Studies, vol. 4, no. 1, pp. 47-56. doi: 10.30525/2256-0742/2018-4-1-350-357

Analiz obsyahiv kontrabandy v Ukrayini: masshtaby, pryami/nepryami vtraty byudzhetu ta ekonomiky (2019). [Contraband analysis in Ukraine: scale, direct / indirect budget and economic losses]. Retrieved November 2019, from: https://platforma-msb.org/analiz-obsyagiv-kontrabandy-v-ukrayini-masshtaby-pryami-nepryami-vtratybyudzhetu-ta-ekonomiky/ (in Ukrainian)

Cherkashin, V., Neshodovsky, I., \& Savarets, A. (2019). Vykorystannya mizhnarodnykh poshtovykh ta ekspres vidpravlen' u skhemakh z ukhylyannya vid splaty mytnykh platezhiv ta shlyakhy protydiyi [Use of international postal and express shipments in customs evasion schemes and countermeasures]. Institute for Socio-Economic Transformation. Kyiv. Retrieved from: https://apitu.files.wordpress.com/ (in Ukrainian)

Pravova doktryna Ukrayiny: Kryminal'no-pravovi nauky v Ukrayini: stan, problemy ta shlyakhy rozvytku (2013). [Legal Doctrine of Ukraine: Criminal law in Ukraine: state, problems and ways of development] / by head. ed. V. Ya. Tatsia, V. I. Borisov. Kharkiv: Law. 5 Vol. 1240 p. (in Ukrainian)

Spivak, I. (2019). Yurydychna osoba yak spetsyfichnyy sub'yekt administratyvnoyi vidpovidal'nosti za porushennya mytnykh pravyl [Legal entity as a specific subject of administrative responsibility for violation of customs rules]. Law and public administration, vol. 1, pp. 65-73. (in Ukrainian) 